\title{
Normas editoriales de la Revista Palobra
}

PALOBRA, es una revista científica en el área de las ciencias sociales, humanas y de educación, dirigida a profesionales, académicos y público en general y publicada anualmente por la Facultad de Ciencias Sociales y Educación de la Universidad de Cartagena (Colombia), cuya misión es el fortalecimiento de sus procesos investigativos, aportando a la popularización del conocimiento.

Los interesados en participar como articulistas de la revista deberán cumplir con sus normas editoriales en los textos que presenten a consideración del Comité Editorial, las cuales están ajustadas a la clasificación y los patrones establecidos por COLCIENCIAS para esta clase de documentos.

La revista PALOBRA requiere que los autores concedan la propiedad de sus derechos de autor, para que sus artículos sean reproducidos, publicados, editados, fijados, comunicados y transmitidos públicamente en cualquier forma o medio, así como su distribución en el número de ejemplares que se requieran y su comunicación pública, en cada una de sus modalidades, incluida su disposición al público a través de medios electrónicos, ópticos o de cualquier otra tecnología para fines exclusivamente científicos, culturales, de difusión y sin fines de lucro.

\section{TIPOS DE ARTÍCULOS}

Las colaboraciones presentadas al Comité Editorial de la Revista Palobra tendrán un formato que se ajuste a la siguiente tipología (según tipología y caracterización establecida por Publindex-Colciencias, 2006):

- Artículo de Investigación Científica (Tipo 1): documento que presenta resultados originales de proyectos de investigación terminados. Su estructura generalmente contempla cuatro (4) apartes: introducción, metodología, resultados y conclusiones.

- Artículo de Reflexión (Tipo 2): Documento que presenta resultados de investigación terminada por el autor desde una perspectiva analítica, interpretativa ó crítica, sobre un tema específico, recurriendo a fuentes originales.

Estos dos tipos de artículos tendrán una extensión que oscile entre 15 y 20 páginas, incluidos el título y resúmenes, en español e inglés.

Los siguientes, tendrán un máximo de extensión entre 12 y 15 páginas, incluyendo el título y resúmenes, en español e inglés: 
- Artículos de Revisión (Tipo 3): Documento resultado de una investigación terminada por el autor donde se analizan, sistematizan e integran los resultados de investigaciones publicadas o no publicadas, sobre un campo temático, con el fin de dar cuenta de avances y tendencias de desarrollo. Se caracteriza por fundamentarse en una revisión bibliográfica rigurosa.

- Artículo de Revisión de Tema: Cuando se expone el resultado de una revisión crítica de la bibliografía sobre un tema que no esté soportada por una investigación científica por parte del autor, superior a 50 referencias.

- Documento de reflexión no derivado inmediatamente de investigación ("Ensayo").

- Documentos de Trabajo: Son textos que adelantan avances teóricos, metodológicos y empíricos sobre casos específicos provenientes de investigaciones en marcha que se someten a escrutinio público.

- Testimonios: Transcripciones de documentos históricos (públicos y privados) no publicados y/o materiales etnográficos (biográficos, relatos, etc.) que se publican (con la debida autorización de las fuentes) para su divulgación.

- Opinión: Documentos que recoge impresiones e interpretaciones del autor sobre circunstancias contextuales presentes.

- Notas: Notas breves y reseñas informativas sobre eventos de interés científico-académico provenientes de las actividades de docencia, investigación y extensión generados ó en los que participe la Facultad de Ciencias Sociales y Educación de la Universidad de Cartagena por intermedio de sus estudiantes y docentes.

\section{PROCESO DE EVALUACIÓN DE ARTÍCULOS}

La revista Palobra se encuentra indexada a COLCIENCIAS y además está aceptada en los siguientes sistemas de resúmenes biblio-hemerográficos: Base de datos bibliográfica de revistas de Ciencias Sociales y Humanidades (CLASE), Sistema de Información Bibliográfica para publicaciones científicas seriadas y periódicas de América Latina, el Caribe, España y Portugal (LATINDEX), DIALNET Y EBSCO HOST.

Se hace claridad que los artículos de investigación sometidos a consideración del Comité Editorial deben ser originales e inéditos, y no deberán estar publicados previamente, ni deben estar sometidos simultáneamente a evaluación de otra publicación.

El proceso de evaluación de artículos científicos se realiza de acuerdo con las siguientes fases: 
- Convocatoria: Las fechas de convocatoria para recibir artículos se programan durante el primer semestre de cada año por un espacio de 30 días.

- Selección de artículos por el Comité Editorial: El proceso de evaluación de artículos de investigación se inicia con la evaluación y selección que realiza el Comité Editorial de la Revista Palobra, de los trabajos que presentados, y que reúnan el máximo de los requisitos para ser publicados. Posteriormente, estos artículos son devueltos a sus autores para que realicen los ajustes necesarios para el lleno total de las normas de publicación en un plazo máximo de 30 días.

- Selección y evaluación de artículos por pares académicos: Todos los artículos originales son sometidos a un proceso de evaluación estrictamente anónima por pares académicos, especialistas o árbitros ad-hoc externos, bajo la modalidad de doble ciego, por lo cual una vez sean recibidos de vuelta por parte de sus autores, el comité editorial selecciona los pares académicos para cada artículo, de acuerdo con su formación y experiencia en el tema, y les envía solicitud de evaluación, el artículo y normas editoriales.

La evaluación de artículos se realiza con base en un formato diseñado por el Comité Editorial de la Revista Palobra.

- Revisión del corrector de estilo: Al mismo tiempo, el corrector de estilo revisa el artículo y hace las recomendaciones pertinentes al artículo, las cuales son enviadas al Comité Editorial.

- Notificación de evaluación a articulistas: Al recibir en un término máximo de 30 días, la evaluación satisfactoria por parte de los pares académicos externos y del corrector de estilo, el Comité editorial envía una notificación al articulista de la evaluación realizada y las observaciones del corrector de estilo, para que realice los ajustes pertinentes en un plazo máximo de 15 días.

En caso de que los pares evaluadores externos recomienden la no aceptación del artículo, esto será comunicado también a los autores por parte del Comité Editorial.

Es válido mencionar que la revista se reserva el derecho a publicar el artículo de acuerdo a la evaluación que realicen los pares evaluadores.

- Edición final: Una vez son recibidos los artículos ajustados por sus autores, el Comité Editorial los revisa nuevamente, así como el corrector de estilo y se procede a realizar los últimos ajustes para iniciar el proceso de edición.

- Autorización de Publicación: Finalmente, a los autores se les envía un formato de autorización de la publicación de su artículo en la revista 
Palobra, el cual debe ser firmado, autenticado y enviado al editor (a) en un plazo máximo de 8 días, a fin de cumplir con todos los requisitos de publicación.

Cuando se publica la revista cada articulista recibe dos (2) ejemplares de la edición donde colaboró y cada par evaluador recibe una (1) edición de la revista donde participó.

\section{REGLAMENTO DE PUBLICACIONES}

- Todos los artículos deben ir precedidos de dos (2) resúmenes (en español e inglés), que no debe superar las 200 palabras, además de 5 palabras claves, en ambos idiomas.

- Los artículos tendrán la siguiente estructura: introducción ó presentación, subcapítulos, conclusiones y/o recomendaciones, así como referencias bibliográficas.

- Las notas deben incluirse al pie de cada página (no al final del artículo). Mientras que las referencias bibliográficas deben insertarse en el texto. La bibliografía no deberá exceder los 15 títulos, excepto para los artículos de revisión de una investigación o de un tema.

- Los artículos deben estar escritos a espacio y medio, en fuente Times New Roman, de 12 puntos. Deberán ser entregados en formato Word (2003 en adelante), en formato digital y una copia impresa.

- Las fotografías, que se propongan para ser incluidas en cualquier tipo de artículo o texto de Palobra deberán ser digitales. Las fotos deberán tener referenciado el asunto, el autor, lugar y fecha en que se realizó. Lo mismo se aplica para los gráficos, diagramas o cualquier material ilustrativo.

- Las palabras en idioma extranjero deben ir en cursiva.

- Las citas textuales deben ir entre comillas y cursivas. En caso de superar los 8 renglones, se harán en párrafo centrado.

- Todas las referencias bibliográficas citadas en los textos deben aparecer al final del artículo. A su vez no podrán aparecer textos en la bibliografía que no se citen en el artículo. La bibliografía deberá hacerse siguiendo las siguientes recomendaciones:

o Libro: Apellidos del autor (Mayúsculas), nombre del autor en minúsculas. año de edición entre paréntesis. Título del libro en cursiva. Lugar de edición: nombre de la editorial. página/s (Pág. o Págs.)

o Artículo de revista: Apellidos del autor (Mayúsculas), nombre del autor en minúsculas. año de edición entre paréntesis. Título del artículo entre 
comillas seguido de la preposición "En": Nombre de la revista en cursiva. Lugar de edición. Nombre de la editorial. Volumen (Vol.). Número de la revista (No.). mes/es entre paréntesis, páginas que comprende el artículo dentro de la revista o página citada (pág. o págs.)

o Prensa: Apellidos del autor (Mayúsculas), nombre. Título del artículo en cursiva. Preposición "En": Nombre del periódico en cursiva, lugar de edición, fecha, página/s (pág. o págs.)

o Documentos de archivos: Denominación del archivo (la primera vez completa y después en iniciales), sección, legajo, expediente, lugar, fecha.

o Publicaciones en Internet: Apellidos del autor (Mayúsculas), nombre del autor en minúsculas. fecha de la publicación entre paréntesis, Título del artículo en cursiva. dirección de la página web, la inscripción: “Fecha de consulta" y el dato respectivo.

- Dentro del texto la forma de citar será: Apellido del autor (Minúscula), año de publicación y página donde aparece la cita. Ej.: (Ortiz, 1998: 20)

- Los textos incluidos en la bibliografía se deben presentar alfabéticamente por el primer apellido de los autores y en orden cronológico ascendente para cada autor.

- Si es artículo de una ponencia, se indicará la respectiva referencia en las notas al final de la primera página del texto.

- Los agradecimientos, en donde los autores reconocen el apoyo al desarrollo del estudio o investigación, son voluntarios. Se debe colocar como nota al final de la página inicial.

Todo artículo debe incluir la biografía de los autores después de la bibliografía así: Nombre y apellidos, formación profesional y postgraduada, adscripción institucional (Dependencia y Universidad/Institución, País), publicaciones de los últimos 5 años, correo electrónico.

Los autores deben manifestar por escrito su consentimiento para publicar el artículo en la revista, mediante una autorización firmada y autenticada por cada uno de ellos.

Los evaluadores tendrán en cuenta los siguientes criterios:

- Calidad del artículo

- Aporte al conocimiento

- Actualidad de la bibliografía

- Calidad y manejo de las fuentes

- Claridad en la argumentación y la redacción

- Importancia y pertinencia del tema de acuerdo a campos temáticos 
El concepto a emitir por los evaluadores puede ser:

- Aprobado sin correcciones

- Aprobado con recomendaciones

- No aprobado

El comité editorial de la revista se reserva el derecho de hacer correcciones menores de estilo.

\section{COBERTURA TEMÁtICA}

Los textos enviados al Comité Editorial deberán vincularse a asuntos localizables dentro de las líneas temáticas siguientes:

- Construcción sociocultural de lo local y lo regional.

- Estructuras de poder en contextos sociales, grupales y estatales.

- Intervención, Trabajo social y contexto.

- Universidad y transformaciones sociales.

- Familia y género.

- Convivencia, desarrollo social y humano.

- Procesos de inclusión y exclusión socio-política.

- Procesos y actores en la construcción de lo público y lo privado.

- Imaginarios, representaciones y discursos.

- Territorio y poblamiento en la región Caribe.

- Pobreza.

- Ciencia, tecnología, sociedad e innovación.

- Educación.

- Comunicación y cultura.

Palobra tiene una distribución local, regional, nacional e internacional, a través de venta y canje con universidades, bibliotecas e instituciones y organizaciones de carácter académico, científico e investigativo y puntos de venta en eventos académicos y científicos. Además, cuenta con una versión virtual colgada en la página WEB de la Universidad de Cartagena http://www.unicartagena. edu.co/palobras.htm

Los artículos, colaboraciones, documentos y correspondencia pueden ser dirigidos a:

\section{COMITÉ EDITORIAL}

\section{Revista Palobra}

Facultad de Ciencias Sociales y Educación

Universidad de Cartagena (Colombia)

Centro, Carrera $6^{\mathrm{a}} \mathrm{N}^{\mathrm{o}} 36-100$.

E-mail: revistapalobra@unicartagena.edu.co

Telefax: (57) 5- 6645706 


\section{Palobra Journal. Editorial Standards}

PALOBRA is a scientific journal in the area of social and human sciences and education, addressed to professionals, academics and the general public. Annually published by the Faculty of Social Sciences and Education of the University of Cartagena (Colombia), whose mission is to strengthen the investigative processes, contributing to the popularization of the knowledge.

Those interested in participating as writers for the journal must meet the following editorial standards while submitting their texts for consideration to the Editorial Committee. The editorial standards are adjust to the classification and patterns established by COLCIENCIAS.

The PALOBRA journal requires authors to grant the copyright ownership of their articles, to be reproduced, published, edited, posted, publicly reported and transmitted in any form or medium, as well as their distribution in the number of copies required for the public disclosure, in each of its forms, including the electronic publicly available, optical or any other technology for purposes strictly scientific, cultural, media and nonprofit.

\section{TYPES OF ARTICLES}

Contributions submitted to the Editorial Committee of the Palobra journal will have a format that fits the following typology (according to typology and characterization established by Publindex-Colciencias, 2006):

- Scientific research article (type 1): A written document that presents original results of completed research projects. The structure generally includes four (4) parts: introduction, methodology, results and conclusions.

- Article of Reflection (type 2): A written document that presents originals results of research projects from an analytical, interpretative, or critical, approach of the author on a specific topic, from original sources.

These two types of articles will have a length of 15 and 20 pages, including title and abstract, in Spanish and English.

The following articles will have extension between 12 and 15 pages maximum, including the title and abstract, in Spanish and English.

- Article of Revision (Type 3): A written document which presents results of research completed by the author, where they are analyzed, systematized and integrated with published or unpublished research results, on a certain thematic field in order to elucidate advances and trends in development. It is characterized by presenting a rigorous bibliographical revision. 
- Single theme article review: When the exposed result of a critical literature review of single theme is not supported by a scientific research of the author, with more than 50 references.

- Reflection paper not immediately derived from research: ("Essay").

- Working papers: These are advanced theoretical, methodological and empirical investigation texts from specific cases in progress that will undergo on the public scrutiny.

- Testimonials: Unpublished transcripts of historical papers (public and private) and / or ethnographic materials (biographies, stories, etc.) That are posted with permission of the sources.

- Opinion: Papers showing the author's impressions and interpretations of the present situation and context.

- Notes: Brief notes and informative reviews, on scientific and academic events interest, from teaching activities, research and extension, in which the students and teachers of the Faculty of Social Sciences and Education at the University of Cartagena have participated.

\section{ARTICLES EVALUATION PROCESS}

Palobra journal is indexed to COLCIENCIAS and is also accepted in the following systems of biblio-hemerographic abstracts: bibliographic database of journals in social sciences and humanities (class), bibliographic information system for scientific publications and newspapers in Latin America, the Caribbean, Spain and Portugal (Latindex), Dialnet and EBSCO host.

Research papers submitted to the Editorial Committee should be original and unpublished and must not be submitted simultaneously to another publication evaluation.

The evaluation processes of scientific articles are made according to the following phases:

- Call: Call dates for articles are scheduled during the first half of each year for a period of 30 days.

- Selection of articles made by the Editorial Committee: The selection process of research articles begins with the evaluation and selection conducted by the Editorial Committee of Palobra journal, to check if it meet the minimum requirements to be published. Later, these articles are returned to their authors in order to make the necessary adjustments for the fulfillment of the publication standards. Authors will have maximum period of 30 days to return the articles. 
- Selection and evaluation of articles made by the academic peer review: All original articles are subject to a strictly anonymous evaluation process by academic peers, specialists and ad-hoc external referees, using the double-blind method. Once they are received back by the authors, the editorial committee will selected academic peers for each article, in accordance with their training and experience on the topic, and will be send a request for evaluation, of the article and the editorial standards.

The article evaluation is made based on a format designed by the Palobra journal Editorial Committee.

- Copyeditor Review: At the same time, the copyeditor reviews the article and makes relevant recommendations to the article, which are send to the Editorial Committee.

- Notification of evaluation to the authors: When the article is received it will take up to 30 days for the notification of the satisfactory evaluation by external academic peers and the copyeditor. The Editorial Committee will send a notification to the author with the observations of the copyeditor. The author will have 15 days to make the necessaries adjustments.

In the event that external peers reviewers recommended the rejection of the article, the Editorial Committee will communicate this to the authors.

It is worth mentioning that the journal reserves the right to publish the paper article according to the evaluation held by the peer reviewers.

Final editing: Once articles are received with the adjustments by their authors, the Editorial Committee and the copyeditor will reviews them again, in order to make the final adjustments to start the editing process.

- Authorization of Release: Finally, an Authorization form will be send to the authors in which they will authorize the publication of the article in the Palobra journal, this form must be signed, certified and sent to the editor within a maximum period of 8 days to comply with all disclosure requirements.

When the journal will be published each author will receives two (2) copies of the edition and each peer evaluator receives one (1) edition of the journal.

\section{REGULATION OF THE PUBLICATIONS}

- All articles must be preceded by two (2) abstracts (in Spanish and English), which should not exceed 200 words, plus 5 keywords in both languages.

- Articles will have the following structure: introduction or presentation, subchapters, conclusions and / or recommendations and references list. 
- Notes should be included at the bottom of each page (not at the end). References should be inserted in the text.

- Articles should be typed one and a half line spacing, font Times New Roman, and 12 points. Must be submitted in Word format (2003 and newest versions), in digital format and a printed copy.

- The photographies, which are proposed to be included in any article or text of Palobra must be digital. The photos should reference the subject, author, place and date of issue. The same applies for graphics, diagrams or any illustrative material.

- Words in foreign languages should be in cursive fonts.

- Cites should be enclosed in quotations and cursive font. In case of being more than 8 lines they shall be done in a centered paragraphs.

- All references cited in the text must appear at the end of the article. It should not appear texts that are not mentioned in the reference list. References list should be done along the following recommendations:

o Book: Author's last name in capitals letters, author's name in lowercase, year of edition in parentheses. Book title in cursive font. Place of publishing: name of publisher.

o Journal article: Author's last name should be in capital letters, author's name in lowercase. year of publication in parentheses. Article's title in quotations, followed by the preposition "In": journal name in cursive font. Place of publication. name of publisher, Volume (Vol.). Issue of the journal (No.), month / $\mathrm{s}$ in Article's parentheses pages comprising the article inside the magazine or page cited (p. or pp.)

o Press: Author's last name in capital letters. Title in cursives Preposition "in" journal name in cursive, place of publication, date, page / s (page or pages.)

o Documents or files: File name (the first completed and then initials), section, folder, file, location, date.

o Internet resource publication: Author's last name in capitals, author's name in lowercase. date of publication in parentheses, Title in cursive font. web page address, the inscription: "Date of consultation" and the respective data.

- In-text quotations: Author's Last name in lowercase, year of publication and page where the quotation appears. Eg (Ortiz, 1998: 20)

- Texts included in the references should be presented alphabetically by last name of the authors in ascending chronological order for each author.

- If is a presentation article, indicate the respective reference in the notes at the end of the first page of text. 
- Acknowledgements, where the authors acknowledge the support of the development of study or research, are volunteers. It should be placed as a footnote to the home page.

Each article should include biography of the authors after the references list as follows: Name, profession and postgraduate training, institutional affiliation (Faculty and University / Institution), publications of the last 5 years, e-mail.

Authors must create a written consent to publish the article in the journal, by an authorization and notarized signed by each of them.

The evaluators will consider the following criteria:

- Quality of article.

- Contribution to knowledge.

- Updated references.

- Quality and management of sources.

- Clarity of argument and writing process.

- Importance and relevance of the subject according to thematic fields.

The concept to be issued by the evaluators can be:

- Approved without corrections

- Approved with recommendations

- Not approved

The journal's editorial committee reserves the right to make minor editorial corrections

\section{THEMATIC COVERAGE}

Texts that will be send to the Editorial Committee should be linked to the following thematic lines:

- Socio-cultural construction of the local and the regional.

- Structures of power in social, group and state contexts.

- Intervention, Social Work and context.

- University and social transformations.

- Family and gender.

- Coexistence, social and human development.

- Processes of inclusion and socio-political exclusion.

- Processes and actors in the construction of public and private.

- Imaginary, performances and discourses.

- Territory and population in the Caribbean region.

- Poverty.

- Science, technology, society and innovation.

- Education.

- Communication and culture. 
PALOBRA journal has local, regional, national and international distribution through sales and exchanges with universities, libraries, institutions and academic organizations, of scientific and research character with sale points in academic and scientific events. It also has a virtual version posted on the website of the University of Cartagena http://www.unicartagena.edu.co/ palobras.htm

Articles, contributions, documents and correspondence can be directed to:

EDITORIAL COMMITTEE

Revista Palobra

Facultad de Ciencias Sociales y Educación

Universidad de Cartagena

Centro, Carrera $6^{\mathrm{a}} \mathrm{N}^{\mathrm{o}} 36-100$.

Telefax 6645706

E-mail: revistapalobra@unicartagena.edu.co 
La impresión de la revista se realizó en papel Propalcote de 240 gramos para portada, y páginas interiores en papel Ecológico 70 gramos. Para la composición general de textos, títulos y subtítulos se empleó la tipografía Carmina. Se aplicaron los programas Word 2007 para la edición de textos, Illustrator para elaboración digital del logo, Photoshop CC 2015 para el retoque y edición de imágenes e Indesign CC 2015 para composición de páginas. Con un tiraje de 100 ejemplares en su décimo séptimo número, la revista Palobra de la Facultad de Ciencias Sociales y Educación de la Universidad de Cartagena se terminó de imprimir en agosto de 2017 en Cartagena de Indias, Colombia. 

U N I VER S I D A D D E C A R T A G E N A

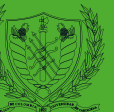

$\sqrt{2}$ 